\title{
Taurolithocholic acid promotes intrahepatic cholangiocarcinoma cell growth via muscarinic acetylcholine receptor and EGFR/ERK1/2 signaling pathway
}

\author{
SUMET AMONYINGCHAROEN $^{1}$, TAWIT SURIYO ${ }^{2}$, APINYA THIANTANAWAT $^{1,2}$, \\ PIYAJIT WATCHARASIT ${ }^{1,2}$ and JUTAMAAD SATAYAVIVAD ${ }^{1-3}$ \\ ${ }^{1}$ Chulabhorn Graduate Institute; ${ }^{2}$ Laboratory of Pharmacology, Chulabhorn Research Institute, \\ Bangkok 10210; ${ }^{3}$ Center of Excellence on Environmental Health and Toxicology, \\ Office of Higher Education Commission, Ministry of Education, Bangkok 10400, Thailand
}

Received November 3, 2014; Accepted February 10, 2015

DOI: 10.3892/ijo.2015.2939

\begin{abstract}
Cholangiocarcinoma (CCA) is a malignant cancer of the biliary tract and its occurrence is associated with chronic cholestasis which causes an elevation of bile acids in the liver and bile duct. The present study aimed to investigate the role and mechanistic effect of bile acids on the CCA cell growth. Intrahepatic CCA cell lines, RMCCA-1 and HuCCA-1, were treated with bile acids and their metabolites to determine the growth promoting effect. Cell viability, cell cycle analysis, EdU incorporation assays were conducted. Intracellular signaling proteins were detected by western immunoblotting. Among eleven forms of bile acids and their metabolites, only taurolithocholic acid (TLCA) concentration dependently (1-40 $\mu \mathrm{M})$ increased the cell viability of RMCCA-1, but not HuCCA-1 cells. The cell cycle analysis showed induction of cells in the $S$ phase and the EdU incorporation assay revealed induction of DNA synthesis in the TLCA-treated RMCCA-1 cells. Moreover, TLCA increased the phosphorylation of EGFR, ERK 1/2 and also increased the expression of cyclin D1 in RMCCA-1 cells. Furthermore, TLCA-induced RMCCA-1 cell growth could be inhibited by atropine, a non-selective muscarinic acetylcholine receptor (mAChR) antagonist, AG 1478 , a specific EGFR inhibitor, or U 0126, a specific MEK 1/2 inhibitor. These results suggest that TLCA induces CCA cell growth via $\mathrm{mAChR}$ and EGFR/EKR1/2 signaling pathway. Moreover, the functional presence of cholinergic system plays a certain role in TLCA-induced CCA cell growth.
\end{abstract}

Correspondence to: Dr Jutamaad Satayavivad, Laboratory of Pharmacology, Chulabhorn Research Institute, 54 Kamphaeng-Phet 6 Rd. Laksi, Bangkok 10210, Thailand

E-mail: jutamaad@cri.or.th

Key words: intrahepatic cholangiocarcinoma, bile acids, taurolithocholic acid, mAChR, EGFR

\section{Introduction}

Cholangiocarcinoma (CCA) is a malignant tumor arising from the biliary tract epithelium, cholangiocyte. The conditions associated with chronic biliary tract inflammation such as primary sclerosing cholangitis (PSC), parasitic infection, viral infection and chemical carcinogen exposure, are major risk factors associated with the development of CCA (1). However, the specific etiology and molecular pathogenesis of CCA remain to be comprehensively elucidated.

Bile acids are endogenous substances which play a role in several important physiological processes (2). Bile acid exposure has been reported to be associated with an increasing incidence of gastrointestinal cancers (3). Bile acids inducing cancer cell proliferation via epidermal growth factor receptors (EGFR), Farnesoid X receptors (FXR), sphingosine 1-phosphate receptor 2 (S1PR2), and G-protein-coupled bile acid receptor 1 (TGR5) have been associated with many types of cancer such as colon, liver and uterus (4-7). Furthermore, deoxycholic acid (DCA), lithocholic acid (LCA) and their taurine conjugates stimulate colon cancer cell proliferation through muscarinic acetylcholine receptor subtype M3 (M3 mAChR) (8-10). However, our knowledge of the roles of bile acids on CCA cell growth is limited and more study is needed.

Cholinergic systems are functionally present on certain types of cancer cells including lung, colon, cervix, prostate and breast cancers (11-15). The cholinergic system plays a role in the regulation of important cell functions, including proliferation, migration, cell-to-cell communication and other features critical for cancer progression $(16,17)$. More importantly, it has been shown that the expression of $\mathrm{M} 3 \mathrm{mAChR}$ plays a key role in the proliferation and metastasis of CCA (18). Furthermore, the cholinergic denervation of the liver results in the induction of cell death and impairs proliferative response of cholangiocyte to cholestasis (19). In the present study, we focused on the effects of different bile acids and their metabolites on the growth of two different intrahepatic CCA cell lines. HuCCA-1 cells were obtained from a Thai-CCA patient with a history of 
parasitic infection (Opisthorchis viverrini), while RMCCA-1 cells were established from a Thai-CCA patient with a history of non-parasitic infection. The mechanistic effect of bile acids in CCA growth was also investigated.

\section{Materials and methods}

Materials. Eleven forms of bile acids and their metabolites were purchased from Sigma-Aldrich (St. Louis, MO, USA). These included cholic acid (CA, purity $\geq 98 \%$ ), chenodeoxycholic acid (CDCA, purity $\geq 97 \%$ ), deoxycholic acid (DCA, purity $\geq 98 \%$ ), lithocholic acid (LCA, purity $\geq 97 \%$ ), glycocholic acid (GCA, purity $\geq 97 \%$ ), glycochenodeoxycholic acid (GCDCA, purity $\geq 97 \%$ ), glycodeoxycholic acid (GDCA, purity $\geq 97 \%$ ), taurocholic acid (TCA, purity $\geq 95 \%$ ), taurochenodeoxycholic acid (TCDCA, purity $\geq 95 \%$ ), taurodeoxycholic acid (TDCA, purity $\geq 97 \%$ ), and taurolithocholic acid (TLCA, purity $\geq 97 \%$ ). Carbachol and oxotremorine-M were also purchased (SigmaAldrich). AG 1478 was obtained from Calbiochem (Germany). U 0126 was ordered from Cell Signaling Technology (Beverly, MA, USA).

Cell culture. The human intrahepatic CCA cell lines, including HuCCA-1 and RMCCA-1 derived from bile duct tumor mass of Thai CCA patients, were established and kindly provided by Professor Stitaya Sirisinha (20), and Dr Kawin Leelawat (21), respectively. Both HuCCA-1 and RMCCA-1 cells were grown in Ham's F-12 medium (Gibco, Carlsbad, CA, USA), supplemented with 10\% FBS (JR Sientific, Inc., Woodland, CA, USA), 2 mM L-glutamine, $100 \mathrm{U} / \mathrm{ml}$ penicillin and $100 \mu \mathrm{g} / \mathrm{ml}$ streptomycin (Gibco), at $37^{\circ} \mathrm{C}$ in a $5 \% \mathrm{CO}_{2}$ humidified atmosphere. Human neuroblastoma SH-SY5Y cells obtained from American Type Culture Collection (ATCC) were grown in a 1:1 mixture of minimum essential medium (MEM) (Gibco) and Ham's F12 medium supplemented with $10 \% \mathrm{FBS}, 2 \mathrm{mM}$ L-glutamine, $100 \mathrm{U} /$ $\mathrm{ml}$ penicillin and $100 \mu \mathrm{g} / \mathrm{ml}$ streptomycin, and cultured in $5 \% \mathrm{CO}_{2}$ at $37^{\circ} \mathrm{C}$ humidified atmosphere.

MTT assay. Cell viability was measured by a quantitative colorimetric assay (MTT) (1-(4,5-Dimethylthiazol-2-yl)-3,5diphenylformazan)(Sigma-Aldrich) showing themitochondrial activity of living cells. Briefly, human CCA cells were plated in 96-well plates ( $1 \times 10^{4}$ cells/well) and cultured overnight for attachment. The next day, cell synchronization was performed by incubating in serum-free medium for $24 \mathrm{~h}$. The synchronized cells were treated with different bile acids and their metabolites for $48 \mathrm{~h}$ in serum-free medium, in order to reduce growth promoting effects of the growth factor and steroid hormones present in the serum. Thereafter, the medium was aspirated, and $100 \mu \mathrm{l}$ of $500 \mu \mathrm{g} / \mathrm{ml}$ of MTT in serum-free medium was added to each well. Cells were incubated with MTT for $4 \mathrm{~h}$; next, cells were lysed by dimethyl sulfoxide. When the formazan crystals were completely dissolved, the optical density (OD) was measured at $570 \mathrm{~nm}$ and reference wavelength at $650 \mathrm{~nm}$, using a SpectroMax M3 microplate reader (Molecular Devices, Sunnyvale, CA, USA).

PrestoBlue cell viability assay. PrestoBlue reagent is quickly reduced by metabolically active cells, providing a quantita- tive measure of viability and cytotoxicity. CCA cells were processed as in the previous MTT assay. At the end of the respective incubation period 24-48 h, cell viability was determined by adding $10 \mu \mathrm{l}$ of 10x PrestoBlue Cell Viability reagent (Invitrogen, Carlsbad, CA, USA) and incubating at $37^{\circ} \mathrm{C}$ for $30 \mathrm{~min}$. The fluorescence was determined at $560 \mathrm{~nm}$ excitation/590 nm emission using SpectroMax M3 microplate reader, and expressed as the percentage of cell viability of the control.

EdU incorporation assay. The cell proliferation was determined by the incorporation of 5-ethynil-2-deoxyuridine (EdU) into newly synthesized DNA stand, using a Click-iT EdU microplate assay kit (Invitrogen) according to the manufacturer's instructions. Briefly, cells were processed as previously described in the cell viability assay. After 24-h treatment with bile acid, $10 \mu \mathrm{l}$ of $10 \mathrm{x}$ EdU working solution was added to each well to make the final concentration of $10 \mu \mathrm{M}$. The incorporation time was $4 \mathrm{~h}$. Then the incorporated EdU in DNA was coupled with Oregon Green-azide dye, and subsequently incubated with horseradish peroxidase-labeled anti-Oregon Green antibody and Amplex UltraRed. The fluorescence was determined at $490 \mathrm{~nm}$ excitation $/ 585 \mathrm{~nm}$ emission using SpectroMax M3 microplate reader, and expressed as the percentage of cell proliferation of the control.

Cell cycle analysis. CCA cells were plated into 6-well plates $\left(1 \times 10^{6}\right.$ cells/well) and cultured overnight. Cells were processed as stated in the previous cell viability assay. After 24-h treatment, cells were trypsinized and washed with cold phosphate buffer saline (PBS). Subsequently, cells were fixed by using $70 \%$ ethanol at $4^{\circ} \mathrm{C}$ for $1 \mathrm{~h}$ and then washed with cold PBS. Cells were stained by adding $1 \mathrm{ml}$ of propidium iodide solution containing $50 \mu \mathrm{g} / \mathrm{ml}$ propidium iodide (Sigma-Aldrich) and $0.5 \mathrm{ng} / \mathrm{ml}$ RNAse (Sigma-Aldrich). Analysis was performed with a BD FACSCanto ${ }^{\mathrm{TM}}$ flow cytometer (BD Biosciences, San Diego, CA, USA) and cell cycle distribution was analyzed by ModFit LT software (Verity House Software, Topsham, ME, USA).

Western blotting. The cells were processed as in the above described cell viability assay. At the end of the respective incubation period, cells were lysed in lysis buffer containing $10 \mathrm{mM}$ Tris (pH 7.4), $150 \mathrm{mM} \mathrm{NaCl}, 1 \%$ Triton X-100, $1 \mathrm{mM}$ PMSF, $1 \mathrm{mM} \mathrm{Na} \mathrm{VO}_{4}, 20 \mathrm{mM} \mathrm{NaF}$ and $1 \mathrm{X}$ protease inhibitor cocktail set I (Calbiochem). Cell lysates were sonicated and incubated at $4^{\circ} \mathrm{C}$ for $30 \mathrm{~min}$ before being centrifuged at $16,000 \mathrm{x} \mathrm{g}$ for $15 \mathrm{~min}$ at $4^{\circ} \mathrm{C}$. The concentration of protein was determined by using Bradford reagent (Bio-Rad, Hercules, CA, USA). The protein $(50 \mu \mathrm{g})$ was electrophoresed onto a 7.5\% SDS-polyacrylamide gel, in a Mini-Protean II system (Bio-Rad). The separated protein bands were transferred onto a nitrocellulose membrane using a Bio-Rad Mini Trans-Blot cell. The nitrocellulose membrane was incubated in blocking buffer (5\% non-fat dry milk in TBST buffer $[10 \mathrm{mM}$ Tris- $\mathrm{HCl}$ $\mathrm{pH}$ 8.0, $150 \mathrm{mM} \mathrm{NaCl}$, and $0.05 \%$ Tween-20)] for $1 \mathrm{~h}$ at room temperature, followed by overnight incubation at $4^{\circ} \mathrm{C}$ with the primary antibody. The antibodies against cyclin D1 $(1: 1,000)$, phospho-ERK1/2 $(1: 2,000)$ and total ERK1/2 (1:2,000) were obtained from Cell Signaling Technology and antibodies 
A

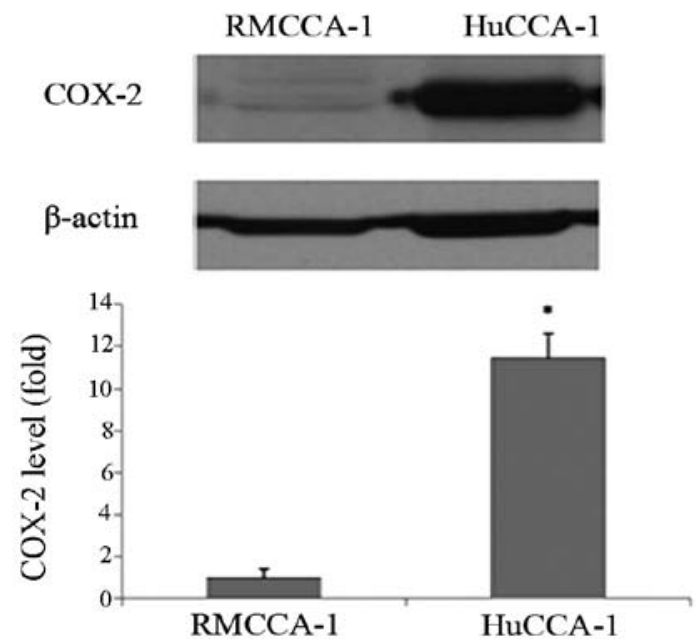

B

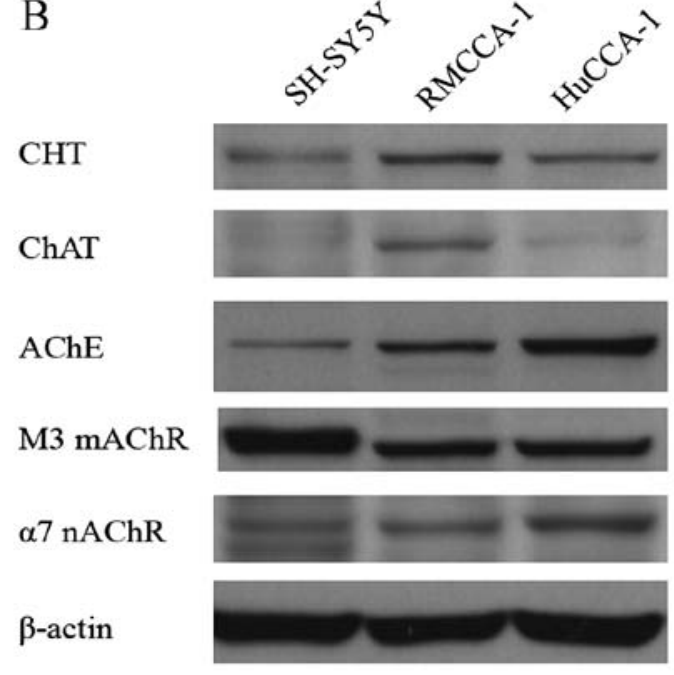

Figure 1. Comparison of COX-2 and cholinergic components in HuCCA-1 and RMCCA-1. (A) Western blotting of COX-2 protein and band density compared between HuCCA-1 and RMCCA-1 ("p<0.05 as compared with RMCCA-1). (B) Western blotting of cholinergic component proteins in SH-SY5Y (used as a positive control), RMCCA-1 and HuCCA-1 cells; CHT, choline transporter; ChAT, choline acetyltransferase; AChE, acetylcholine esterase; M3 mAChR, M3 muscarinic acetylcholine receptor; $\alpha 7 \mathrm{nAChR}, \alpha 7$ nicotinic acetylcholine receptor.

against phospho-EGFR (1:1,000), EGFR $(1: 1,000), \mathrm{COX}-2$ $(1: 2,000)$, CHT $(1: 2,000)$, ChAT $(1: 2,000)$, AChE $(1: 1,000)$, M3 mAChR $(1: 1,000)$ and $\alpha 7 \mathrm{nAChR}(1: 1,000)$ were purchased from Santa Cruz Biotechnology (Santa Cruz, CA, USA). The membrane was washed three times for $10 \mathrm{~min}$ each with TBST, and then incubated for $2 \mathrm{~h}$ at room temperature with appropriate secondary antibody conjugated with horseradish peroxidase. The protein bands stained with the antibodies were visualized by using enhanced chemiluminescence (ECL) (GE Healthcare, UK). The intensity of protein bands was quantified by Image Quant TL software (GE Healthcare).

Statistical analysis. The experiments were performed in triplicate, and the results are expressed as the means \pm SEM. For individual comparison, statistical analysis was performed using a two-tailed Student's t-test. Multiple comparisons were performed using one-way analysis of variance (ANOVA) followed by the Student-Newman-Keuls test. Data with statistical values of $\mathrm{p}<0.05$ are considered as statistically significant.

\section{Results}

The existence of inflammation marker, $C O X-2$ and cholinergic components in HuCCA-1 and RMCCA-1 cells. The endogenous background levels of inflammation and cholinergic components in CCA cells were determined. The results showed that HuCCA-1 cells have higher expression level (11.5 times) of COX-2, a key inflammatory marker protein than RMCCA-1 cells (Fig. 1A). Furthermore, the existence of cholinergic systems was also different among these two CCA cell lines. All of the cholinergic components including choline transporter (CHT), choline acetyltransferase (ChAT), acetylcholine esterase (AChE), M3 muscarinic acetylcholine receptor $(\mathrm{M} 3 \mathrm{mAChR})$ and $\alpha 7$ nicotinic acetylcholine receptor ( $\alpha 7 \mathrm{nAChR}$ ) were detected in both HuCCA-1 and RMCCA-1 cells (Fig. 1B). Note that, RMCCA-1 cells expressed higher levels of CHT and ChAT than HuCCA-1 cells. Respectively, AChE and $\alpha 7 \mathrm{nAChR}$ expression was lower in RMCCA-1 than HuCCA-1 cells. It is interesting to note that both CCA cell lines expressed higher levels of the cholinergic components than dopaminergic/cholinergic neuroblastoma SH-SY5Y cells, except the M3 mAChR.

TLCA increases viability of RMCCA-1 cells. After treatment with bile acids and metabolites for $48 \mathrm{~h}$, cell viability was determined by MTT assay. As shown in Table I, most of primary bile acids, secondary bile acids and their glycineconjugated at the highest-tested concentration $(100 \mu \mathrm{M})$ significantly decreased the viability of CCA cells, except CA and GCDCA in RMCCA-1 cells. Tauroline-conjugated bile acids at the highest-tested concentration did not significantly decrease the viability of CCA cells, except TCGCA and TLCA in HuCCA-1, and TLCA in RMCCA-1 cells. Primary bile acid CDCA showed higher cytotoxic effect to the CCA cells than another primary bile acid CA. In addition, secondary bile acids, including DCA and LCA, showed higher cytotoxic effects to the CCA cells than their primary bile acids. It is interesting to find that among the 11 forms of bile acid and their metabolites only low tested concentration $(0.1-10 \mu \mathrm{M})$ of TLCA increased the viability of RMCCA-1 cells. However, at high concentration decreasing of cell viability was observed. The effect of TLCA to increase cell viability was confirmed by using the PrestoBlue cell viability assay. The results obtained from PrestoBlue cell viability assay showed a similar pattern of MTT assay with a higher sensitivity (Fig. 2). TLCA significantly increased the RMCCA-1 viable cells starting at $5 \mu \mathrm{M}$ until $40 \mu \mathrm{M}$. However, concentrations $>40 \mu \mathrm{M}$ of TLCA caused decreasing trends of cell viability. Note that TLCA at the concentration of $10 \mu \mathrm{M}$ was selected for further study.

TLCA induces RMCCA-1 cell growth. Our results revealed that TLCA increased the RMCCA-1 cell viability in serum- 
Table I. The effects of bile acids and metabolites on cell viability.

Cell viability (\% of control)

\begin{tabular}{|c|c|c|c|c|c|c|c|c|}
\hline \multirow[b]{3}{*}{ Bile acids and metabolites } & \multirow{2}{*}{\multicolumn{4}{|c|}{ RMCCA- 1 concentration $(\mu \mathrm{M})$}} & & & & \\
\hline & & & & & \multicolumn{4}{|c|}{ HuCCA-1 concentration $(\mu \mathrm{M})$} \\
\hline & 0.1 & 1 & 10 & 100 & 0.1 & 1 & 10 & 100 \\
\hline Cholic acid (CA) & $104.2 \pm 4.2$ & $105.0 \pm 3.8$ & $104.7 \pm 2.6$ & $100.5 \pm 2.2$ & $103.0 \pm 2.5$ & $100.6 \pm 2.6$ & $100.6 \pm 1.4$ & $88.4 \pm 3.6^{\mathrm{a}}$ \\
\hline $\begin{array}{l}\text { Chenodeoxycholic acid } \\
\text { (CDCA) }\end{array}$ & $104.6 \pm 0.7$ & $100.4 \pm 1.1$ & $96.8 \pm 2.8$ & $51.8 \pm 3.8^{\mathrm{a}}$ & $103.1 \pm 2.4$ & $104.8 \pm 1.9$ & $100.2 \pm 3.2$ & $49.9 \pm 2.8^{\mathrm{a}}$ \\
\hline Deoxycholic acid (DCA) & $106.8 \pm 1.6$ & $107.3 \pm 1.1$ & $102.3 \pm 8.5$ & $48.4 \pm 2.1^{\mathrm{a}}$ & $93.5 \pm 6.6$ & $95.0 \pm 0.7$ & $86.2 \pm 6.1$ & $27.4 \pm 1.0^{\mathrm{a}}$ \\
\hline Lithocholic acid (LCA) & $104.6 \pm 0.7$ & $104.0 \pm 2.9$ & $56.3 \pm 1.0^{\mathrm{a}}$ & $7.5 \pm 0.8^{\mathrm{a}}$ & $106.7 \pm 1.0$ & $103.9 \pm 4.0$ & $55.2 \pm 5.9^{\mathrm{a}}$ & $5.0 \pm 0.7^{\mathrm{a}}$ \\
\hline \multicolumn{9}{|l|}{ Glycine conjugated bile acids } \\
\hline Glycocholic acid (GCA) & $94.6 \pm 2.7$ & $93.9 \pm 0.7$ & $93.1 \pm 1.7$ & $85.3 \pm 2.9^{\mathrm{a}}$ & $106.1 \pm 2.1$ & $94.7 \pm 1.1$ & $93.3 \pm 0.2$ & $82.0 \pm 3.6^{\mathrm{a}}$ \\
\hline $\begin{array}{l}\text { Glycochenodeoxycholic acid } \\
\text { (GCDCA) }\end{array}$ & $102.0 \pm 1.0$ & $98.2 \pm 1.6$ & $94.3 \pm 6.5$ & $83.5 \pm 7.3$ & $106.5 \pm 2.1$ & $100.6 \pm 1.7$ & $92.3 \pm 1.2^{\mathrm{a}}$ & $77.7 \pm 2.7^{\mathrm{a}}$ \\
\hline $\begin{array}{l}\text { Glycodeoxycholic acid } \\
\text { (GDCA) }\end{array}$ & $97.5 \pm 2.5$ & $91.6 \pm 2.1$ & $94.7 \pm 2.3$ & $86.7 \pm 1.4^{\mathrm{a}}$ & $105.2 \pm 4.1$ & $104.2 \pm 5.1$ & $98.4 \pm 2.4$ & $77.5 \pm 0.1^{\mathrm{a}}$ \\
\hline \multicolumn{9}{|l|}{ Taurine conjugated bile acids } \\
\hline Taurocholic acid (TCA) & $100.4 \pm 3.2$ & $98.4 \pm 3.7$ & $99.7 \pm 5.6$ & $95.5 \pm 5.4$ & $108.1 \pm 3.2$ & $106.9 \pm 2.9$ & $107.3 \pm 4.0$ & $94.4 \pm 3.2$ \\
\hline $\begin{array}{l}\text { Taurochonodeoxycholic acid } \\
\text { (TCGCA) }\end{array}$ & $95.3 \pm 3.6$ & $99.7 \pm 3.8$ & $95.5 \pm 4.9$ & $84.6 \pm 8.0$ & $98.7 \pm 2.0$ & $96.8 \pm 3.3$ & $91.1 \pm 3.2$ & $73.4 \pm 6.6^{\mathrm{a}}$ \\
\hline Taurodeoxycholic acid (TDCA) & $100.8 \pm 1.2$ & $102.6 \pm 1.7$ & $100.4 \pm 3.3$ & $95.2 \pm 2.7$ & $106.5 \pm 2.5$ & $105.7 \pm 2.2$ & $102.2 \pm 2.9$ & $89.5 \pm 5.2$ \\
\hline Taurolithocholic acid (TLCA) & $109.8 \pm 1.7$ & $112.0 \pm 8.2$ & $118.3 \pm 1.3^{\mathrm{a}}$ & $80.1 \pm 6.2^{\mathrm{a}}$ & $95.1 \pm 1.6$ & $98.1 \pm 1.8$ & $94.4 \pm 2.5$ & $55.3 \pm 7.1^{\mathrm{a}}$ \\
\hline
\end{tabular}

Values are mean \pm SE. ${ }^{\mathrm{a}} \mathrm{p}<0.05$.

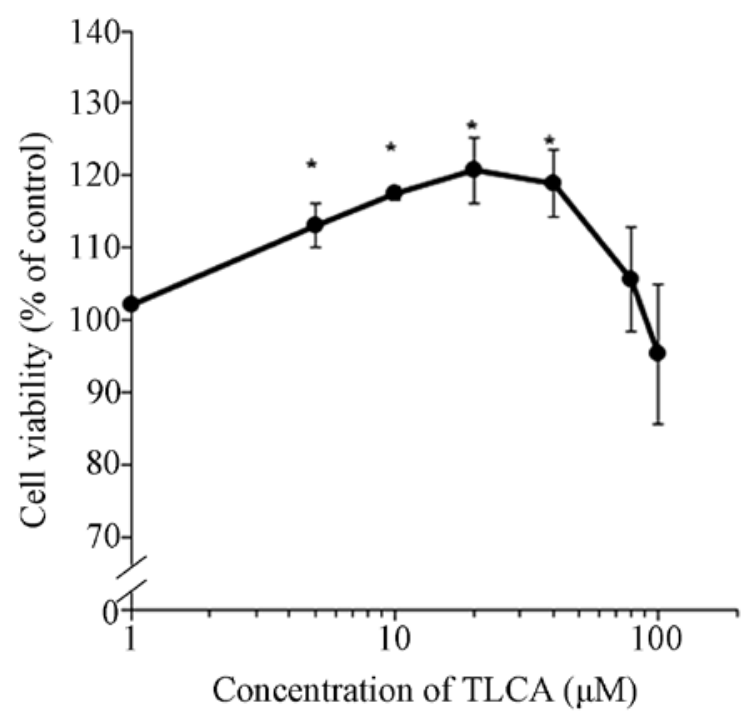

Figure 2. PrestoBlue cell viability assay of RMCCA-1 cells treated with TLCA at $1,5,10,20,40,80$ and $100 \mu \mathrm{M}$ for $48 \mathrm{~h}\left({ }^{*} \mathrm{p}<0.05\right.$ as compared with control).

free conditions, suggesting the growth promoting effect of TLCA. Therefore, further study was conducted to investigate the effect of TLCA on cell cycle and DNA synthesis of RMCCA- 1 cells. The results showed that $10 \mu \mathrm{M}$ of TLCA and the positive control (10\% FBS) treatment for $24 \mathrm{~h}$ signifi- cantly increased the percentage of S-phase cell subpopulation (Fig. 3A). Moreover, the effect of TLCA on the proliferation of RMCCA-1 was detected by the EdU incorporation assay. TLCA at the concentration of $10 \mu \mathrm{M}$ and $10 \%$ of FBS treatment significantly increased cell proliferation by 22.3 and $73.8 \%$, respectively, when compared with the control (Fig. 3B). These results indicate that the rise in TLCA-treated cell viability was caused by cell proliferation. Furthermore, cyclin D1 and phosphorylated-ERK 1/2 of RMCCA-1 cells treated with TLCA were increased in a concentration-dependent pattern, a statistically significant difference at the concentration of $10 \mu \mathrm{M}$ (Fig. 4). Additionally, time course study showed that $10 \mu \mathrm{M}$ of TLCA continuously increases the phosphorylation of ERK 1/2 and EGFR (Fig. 5), indicating the activation of these proteins. The activation of ERK $1 / 2$ was observed at $15 \mathrm{~min}$ following the TLCA treatment, and this activation remained consistent throughout the exposure time $(24 \mathrm{~h})$. The activation of EGFR was also found at 15 min after treatment, and this activation was time-dependent. Despite induction of their phosphorylated forms, the levels of total forms of ERK 1/2 and EGFR were not changed at any time on the TLCA treatment. These results indicate that TLCA induces cell growth and activates the phosphorylation of both EGFR and ERK 1/2 in RMCCA-1 cells.

Muscarinic acetylcholine receptors involved in TLCAactivated RMCCA-1 cell growth. Cholinergic system plays an important role in cholangiocyte biology including modu- 


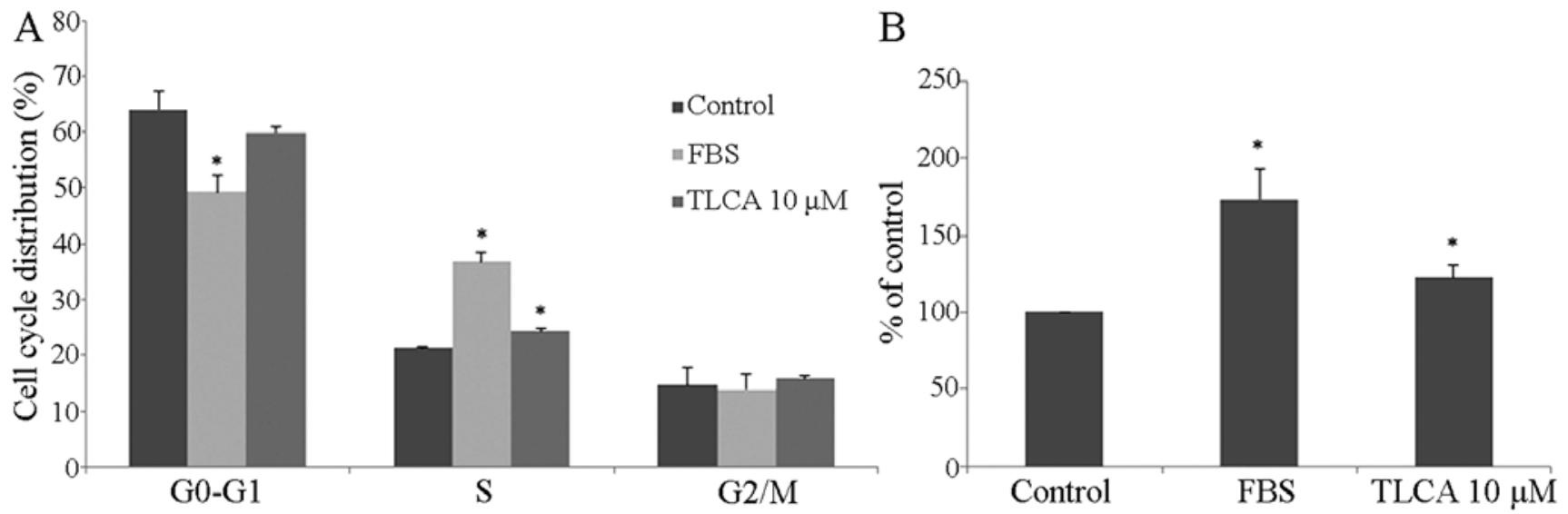

Figure 3. TLCA effects on the growth of RMCCA-1 cells. RMCCA-1 cells were treated with fetal bovine serum (10\% v/v) or TLCA (10 $\mu \mathrm{M})$ for $24 \mathrm{~h}$ and then stained with propidium iodide. Cell cycle was analyzed by ModFit LT software. (A) Cell distribution of cell cycle analysis. (B) RMCCA-1 cell proliferation was determined by using EdU incorporation assay ("p $<0.05$ as compared with control).

A
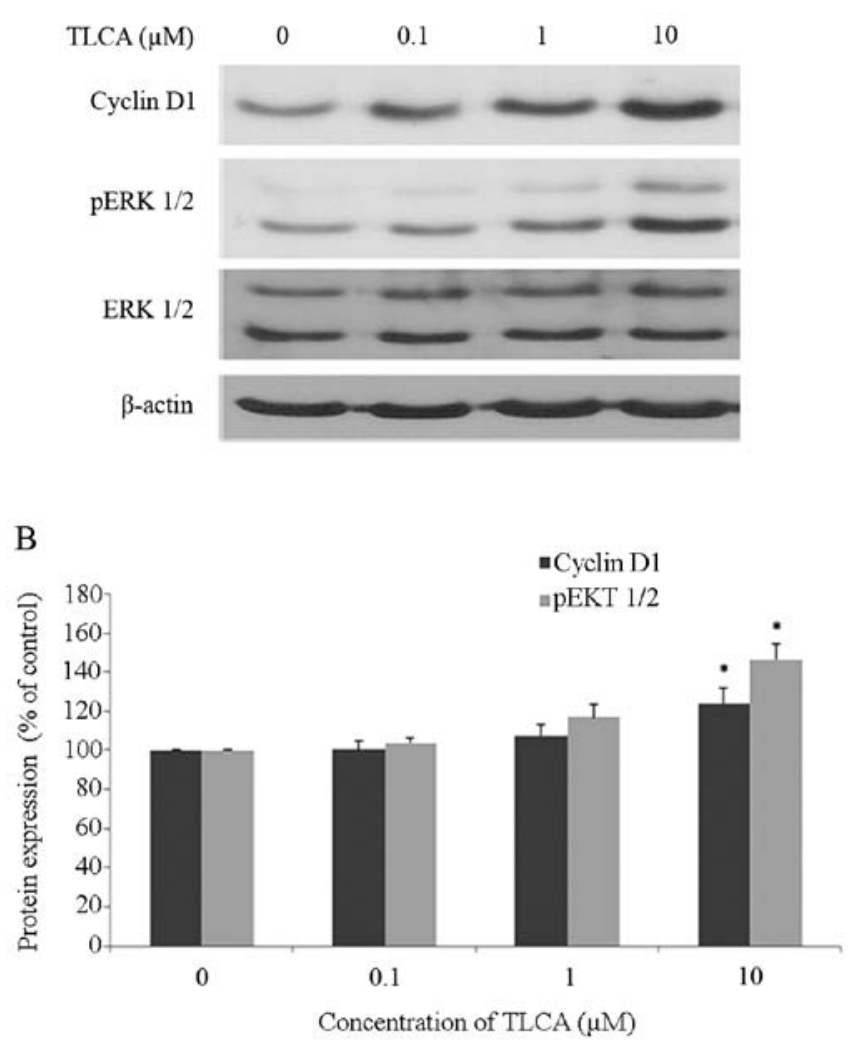

Figure 4. Effect of TLCA on cyclin D1 and pERK 1/2. (A) Western blot bands of cyclin D1, pERK 1/2, ERK $1 / 2$ and $\beta$-actin protein of RMCCA-1 cells treated with TLCA for $48 \mathrm{~h}$. (B) The band density ratio of cyclin D1 and pERK $1 / 2$ protein was determined ( $\mathrm{p}<0.05$ as compared with control).

lating growth, apoptosis, and secretion of cholangiocytes (22). Importantly, mAChR subtype M3 (M3 mAChR) plays a key role in the proliferation and metastasis of CCA (18). To investigate the functional role of cholinergic system in CCA cell growth, HuCCA-1 and RMCCA-1 cells were treated with carbachol, which is a stable cholinergic receptor agonist or oxotremorine-M (Oxo-M), a specific mAChR agonist, in a serum-free condition; then cell viability was determined after

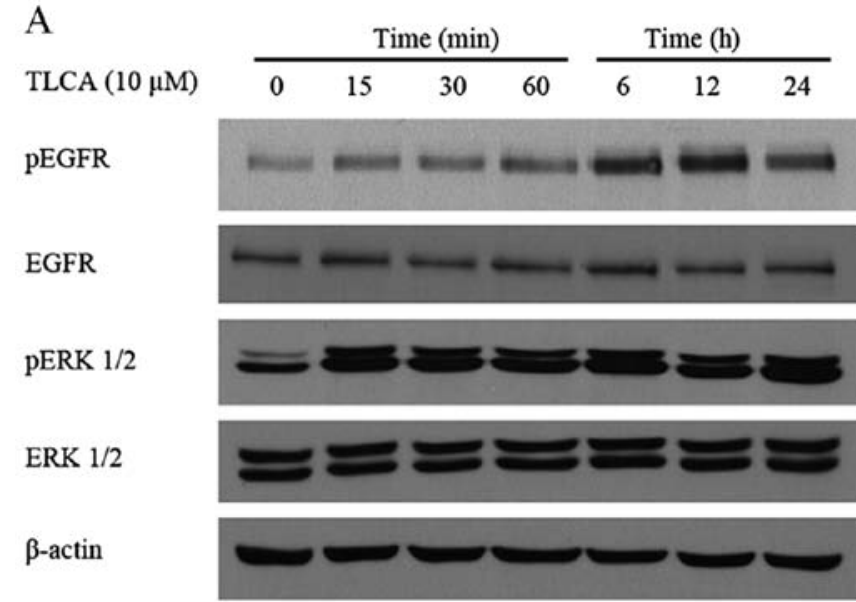

B

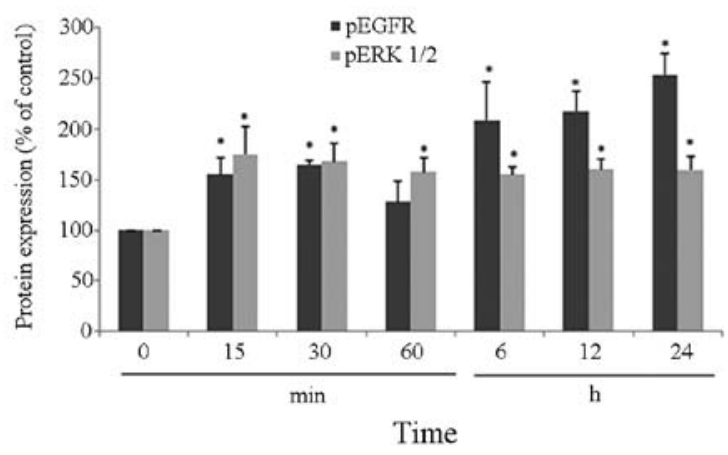

Figure 5. Effects of TLCA on EGFR and ERK. (A) Western blot bands of pEGFR, EGFR, pERK 1/2, ERK $1 / 2$ and $\beta$-actin protein of RMCCA-1 cells treated with TLCA $10 \mu \mathrm{M}$ at varying times. (B) The band density ratio of pEGFR and pERK $1 / 2$ protein was determined ("p $<0.05$ as compared with time $0 \mathrm{~min}$ ).

$48 \mathrm{~h}$ of exposure. The results showed that $0.01 \mu \mathrm{M}$ of carbachol significantly increased the growth of RMCCA-1 cells (Fig. 6A). Carbachol at the higher concentration (0.1-100 $\mu \mathrm{M})$ also increased the growth of RMCCA-1 cells, however significant difference to the control group was not observed. Moreover, none of the tested concentration of carbachol (0.001$100 \mu \mathrm{M}$ ) showed a growth promoting effect in HuCCA-1 cells. 

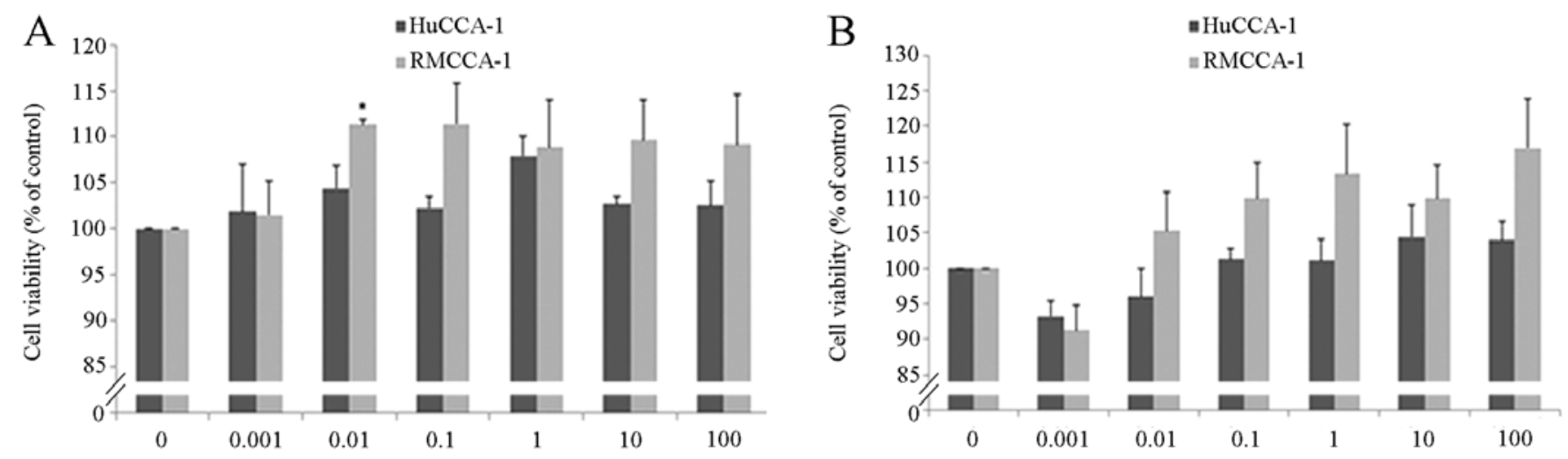

Concentration of Carbachol $(\mu \mathrm{M})$

Concentration of Oxotremorine-M $(\mu \mathrm{M})$

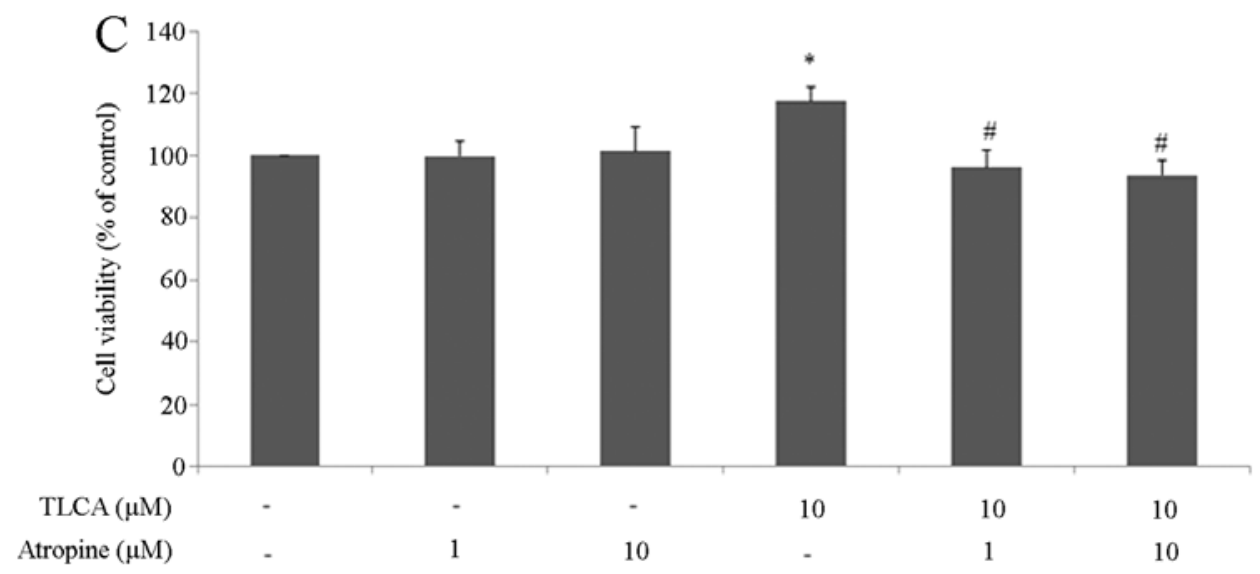

Figure 6. Effect of acetylcholine receptor agonists and TLCA on CCA cell lines. (A) PrestoBlue cell viability of HuCCA-1 and RMCCA-1 cells treated with carbachol for $48 \mathrm{~h}$. (B) PrestoBlue cell viability of HuCCA-1 and RMCCA-1 cells treated with oxotremorine for $48 \mathrm{~h}$. (C) PrestoBlue cell viability of RMCCA-1 cells treated with TLCA and/or atropine for $48 \mathrm{~h}\left({ }^{*} \mathrm{p}<0.05\right.$ as compared with control; ${ }^{\#} \mathrm{p}<0.05$ as compared with TLCA $\left.10 \mu \mathrm{M}\right)$.

Furthermore, Oxo-M (0.01-100 $\mu \mathrm{M})$ also slightly increased the growth of RMCCA-1 cells but this effect was not found in HuCCA-1 cells (Fig. 6B). We observed that the increase in cell viability induced by two cholinergic agonists, HuCCA-1 was less responsive than RMCCA-1. The different results observed in RMCCA-1 and HuCCA-1 cell lines may be due to the difference in the basal cholinergic function of these two cell lines. However, these results may suggest that cholinergic system plays some role in RMCCA-1 cell growth.

To investigate the role of $\mathrm{mAChR}$ in TLCA-induced RMCCA-1 cell growth, RMCCA-1 cells were treated with $10 \mu \mathrm{M}$ of TLCA and/or $1,10 \mu \mathrm{M}$ of atropine, which is a nonselective antagonist of $\mathrm{mAChR}$ for $48 \mathrm{~h}$. The results showed that atropine by itself did not alter the growth of RMCCA-1 cells, whereas atropine completely mitigated the growth promoting effect of TLCA (Fig. 6C). This result indicates that mAChR is involved in TLCA-stimulated RMCCA- 1 cell growth.

It has been reported that some forms of bile acids, including DCA, LCA, GDCA, TDCA, GLCA and TLCA, induced growth of colon cancer cells, through the M3 mAChR-transactived EGFR signaling pathway (10). Next, we investigated the role of M3 mAChR in TLCA-induced activation of EGFR in RMCCA-1. The cells were treated with $10 \mu \mathrm{M}$ of TLCA or $10 \mu \mathrm{M}$ of atropine for $1 \mathrm{~h}$ before western blotting. For combined-treatment, RMCCA-1 cells were pre-treated with $10 \mu \mathrm{M}$ of atropine for $30 \mathrm{~min}$ before being co-exposed with $10 \mu \mathrm{M}$ of TLCA. The result showed that phosphorylatedEGFR significantly increased with a single-treatment of atropine or TLCA while combined-treatment did not reduce the activation of EGFR (Fig. 7). Furthermore, the increase of ERK 1/2-phosphorylated form by TLCA was not reduced in the atropine/TLCA co-treatment group (Fig. 7).

TLCA induces RMCCA-1 cell growth through activation of EGFR/ERK1/2 signaling pathway. EGFR is a membrane receptor that plays an important role in regulating cell proliferation and death. The hypothesis that TLCA induces CCA cell growth through activation of EGFR was tested using AG 1478, which is a specific inhibitor of EGFR. RMCCA-1 cells were pretreated with AG 1478 for 30 min before being treated with EGF or TLCA for $24 \mathrm{~h}$, and cell viability was detected by PrestoBlue reagent. The results showed that $100 \mathrm{ng} / \mathrm{ml}$ of EGF or $10 \mu \mathrm{M}$ of TLCA increased cell viability to 113 and $118 \%$ of control, respectively. Furthermore, pre- and co-treatment with AG 1478 mitigated growth promoting effects of both EGF and TLCA. Moreover, AG 1478 by itself did not affect cell viability (Fig. 8A). These results demonstrate that the activa- 

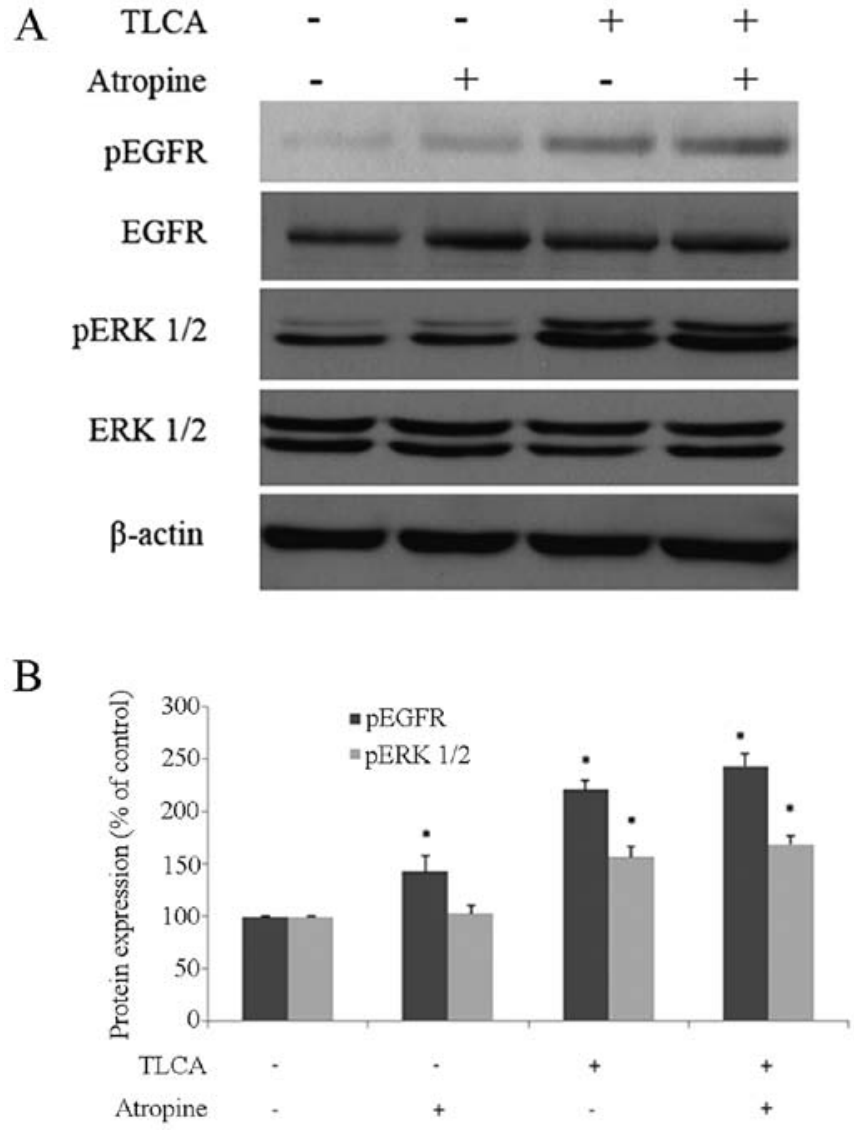

Figure 7. M3 AChR did not transactivate the EGFR. (A) Western blot bands of pEGFR, EGFR, pERK 1/2, ERK $1 / 2$ and $\beta$-actin protein of RMCCA-1 cells treated with TLCA $10 \mu \mathrm{M}$ and/or atropine $10 \mu \mathrm{M}$ at $1 \mathrm{~h}$. (B) The band density ratio of pEGFR and pERK $1 / 2$ protein ( $\mathrm{p}<0.05$ as compared with control).

tion of EGFR is involved in TLCA-induced RMCCA-1 cell growth.

To investigate the involvement of MAP kinase pathway in TLCA-induced CCA cell growth, RMCCA-1 cells were pretreated with $0.1 \mu \mathrm{M}$ of $\mathrm{U} 0126$, which is a MEK $1 / 2$ inhibitor, for $30 \mathrm{~min}$ before being treated with TLCA for $48 \mathrm{~h}$. The results showed that $0.1 \mu \mathrm{M}$ of $\mathrm{U} 0126$ did not affect RMCCA-1 cell viability, but at this concentration, U 0126 significantly attenuated the effects of TLCA-induced RMCCA-1 cell viability at TLCA $10 \mu \mathrm{M}$ (Fig. 8B). These results suggested that MAP kinase pathway is involved in TLCA-induced RMCCA-1 cell growth.

Western blotting of TLCA and/or AG 1478 treated RMCCA-1 cells was performed in order to investigate the role of EGFR signaling pathway on TLCA-induced ERK 1/2 activation. For a single treatment, RMCCA-1 cells were treated with either $10 \mu \mathrm{M}$ of TLCA, or $0.1 \mu \mathrm{M}$ of AG 1478 for $6 \mathrm{~h}$. For combined-treatment, RMCCA-1 cells were pre-treated with $0.1 \mu \mathrm{M}$ of AG 1478 for 30 min before being co-exposed with $10 \mu \mathrm{M}$ of TLCA. The result showed that phosphorylated-EGFR was increased in TLCA single treatment, whereas combinedtreatment of TLCA with AG 1478 significantly reduced TLCA-induced phosphorylation of EGFR (Fig. 9B). In addition, the increase of ERK 1/2-phosphorylated form by TLCA was also significantly reduced in AG 1478/TLCA co-treatment group (Fig. 9B). It should be noted that AG 1478 treatment
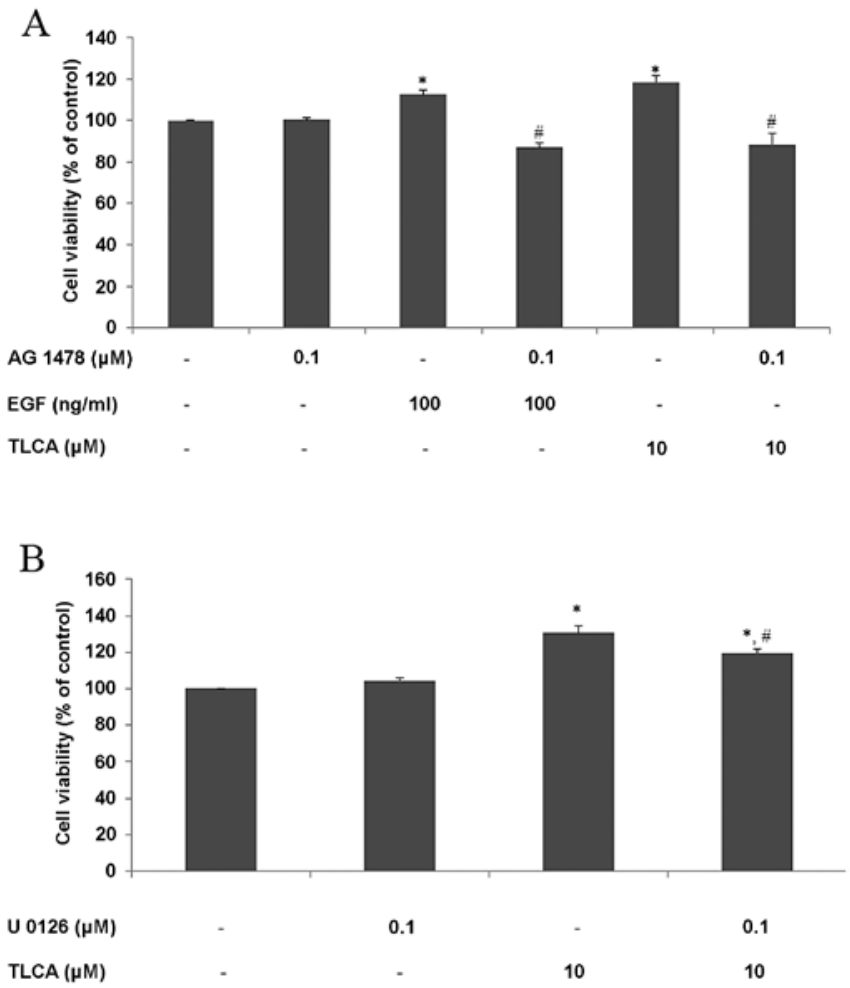

Figure 8. TLCA effects on EGFR and MAP kinase of RMCCA-1 cells. PrestoBlue cell viability assay was used. (A) RMCCA-1 cells were treated with EGF $100 \mathrm{ng} / \mathrm{ml}$ or TLCA $10 \mu \mathrm{M}$ with or without co-incubation AG 1478 for $24 \mathrm{~h}$. (B) RMCCA-1 cells were treated with TLCA $10 \mu \mathrm{M}$ and/or U 0126 for $48 \mathrm{~h}\left({ }^{*} \mathrm{p}<0.05\right.$ was compared with control; ${ }^{*} \mathrm{p}<0.05$ as compared with EGF $100 \mathrm{ng} / \mathrm{ml}$ or TLCA $10 \mu \mathrm{M})$.

by itself dramatically reduced activation of both EGFR and ERK1/2. These results demonstrated that TLCA induces activation of ERK1/2 signaling pathway in part via EGFR. Furthermore, U 0126 was used to support the signaling cascade via MAP kinase pathway. RMCCA-1 cells were treated with TLCA $10 \mu \mathrm{M}$ and/or U $01260.1 \mu \mathrm{M}$ for $24 \mathrm{~h}$. For combinedtreatment, RMCCA-1 cells were pre-treated with $0.1 \mu \mathrm{M}$ of $\mathrm{U} 0126$ for $30 \mathrm{~min}$, before being co-exposed with $10 \mu \mathrm{M}$ of TLCA. The results show that TLCA significantly increased phosphorylated-ERK $1 / 2$ protein, while combined-treatment of TLCA and U 0126 significantly reduced phosphorylatedERK 1/2 protein, when compared with TLCA alone (Fig. 9D). These results suggested that TLCA induces RMCCA-1 cell growth through MAP kinase signaling pathway. Collectively, the results imply that EGFR activated MAP kinase signaling pathway may be involved in TLCA-induced RMCCA- 1 cell growth.

\section{Discussion}

The present study provides further understanding of the potential molecular mechanism underlying the bile acid-induced bile duct cancer development and progression. We showed that among the various forms of bile acid, TLCA can induce growth of RMCCA-1 cells via EGFR/ERK1/2 signaling pathway. Importantly, the functional presence of cholinergic system in CCA plays a certain role on this growth promoting effect of TLCA. 

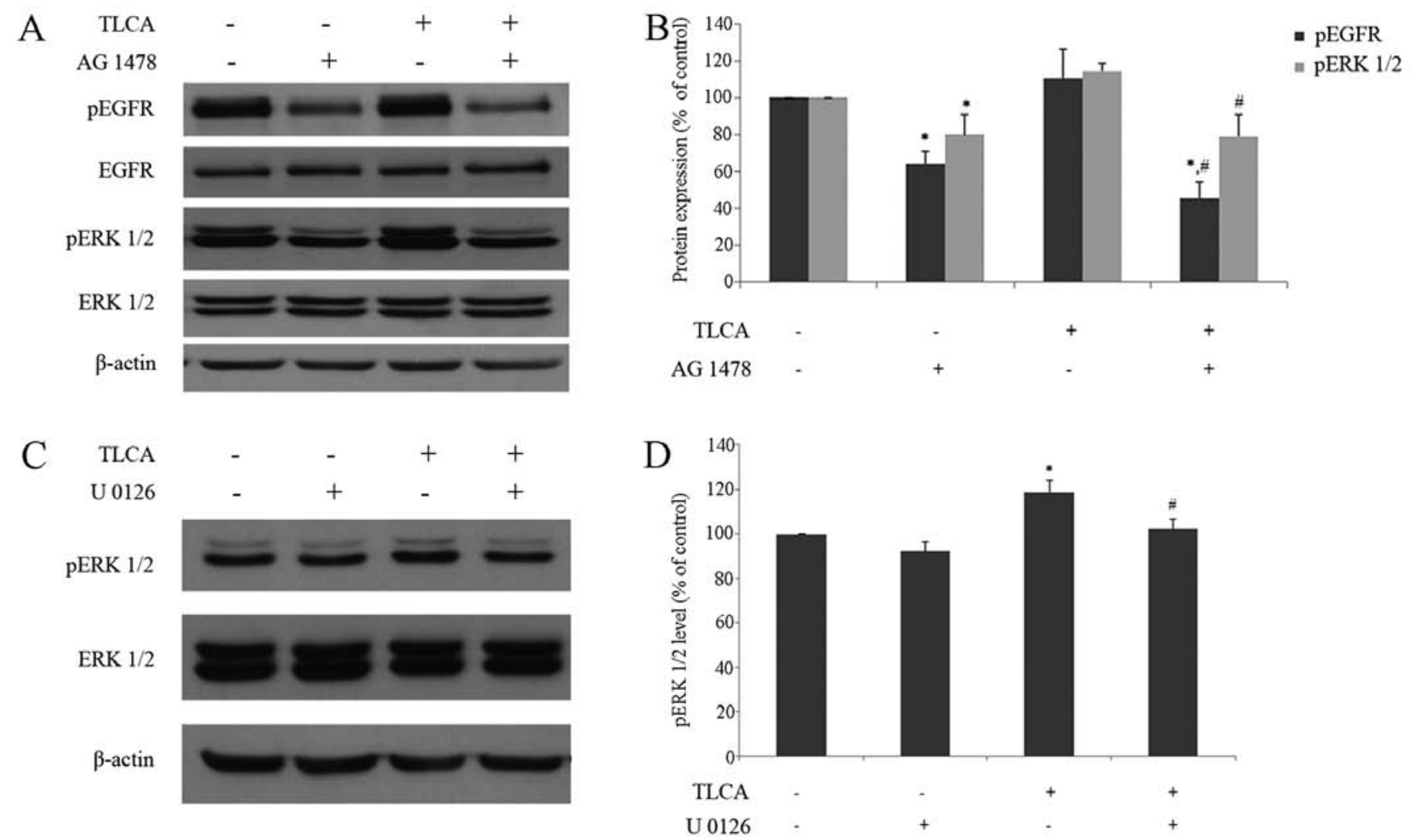

Figure 9. TLCA activates MAP kinase via the EGFR receptor. (A) Western blot bands of pEGFR, EGFR, pERK 1/2, ERK $1 / 2$ and $\beta$-actin protein of RMCCA-1 cells treated with TLCA $10 \mu \mathrm{M}$ and/or AG $14780.1 \mu \mathrm{M}$ at $6 \mathrm{~h}$. (B) The band density ratio of pEGFR and pERK $1 / 2$ protein. (C) Western blot bands of pERK 1/2, ERK1/2, and $\beta$-actin protein of RMCCA-1 cells treated with TLCA $10 \mu \mathrm{M}$ and/or U $01260.1 \mu \mathrm{M}$ at $24 \mathrm{~h}$. (D) The band density ratio of pERK $1 / 2$ protein ( $\mathrm{p}<0.05$ as compared with control; $" \mathrm{p}<0.05$ as compared with TLCA $10 \mu \mathrm{M}$ ).

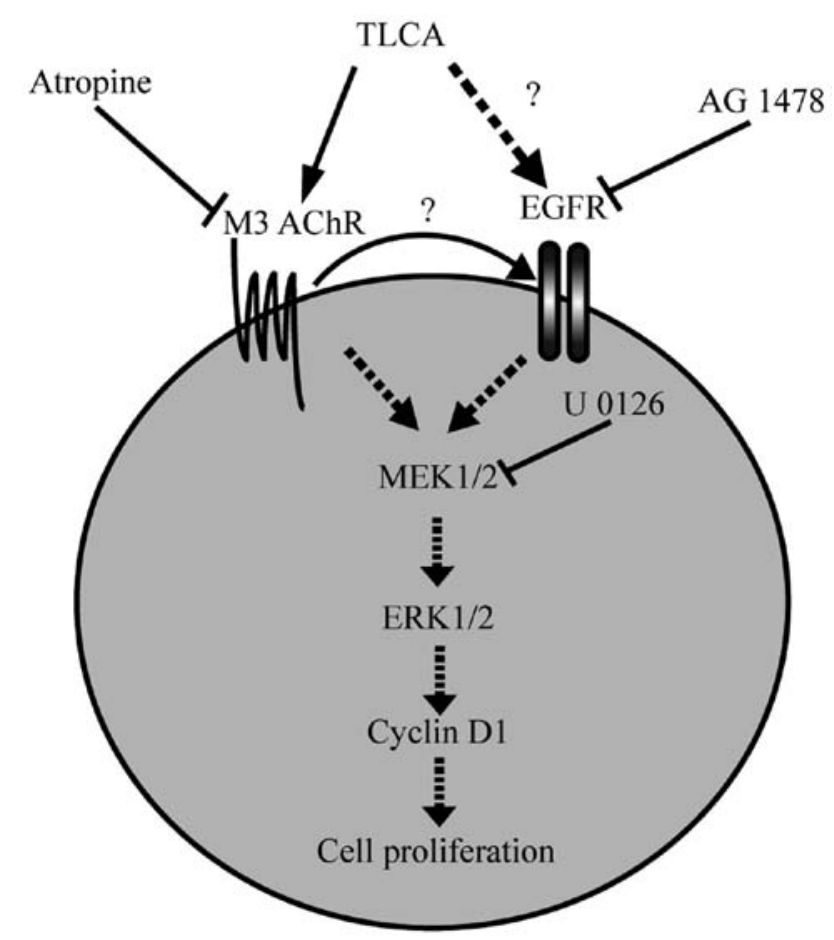

Figure 10. Proposed diagram of signaling pathways of TLCA mediated RMCCA-1 proliferation. TLCA binds to M3 AChR, which can be blocked by a non-selective $\mathrm{mAChR}$ antagonist (atropine). TLCA activates EGFR, which can be blocked by EGFR kinase inhibitor (AG 1478). Activation of M3 AChR and EGFR resulted in activated downstream MAP kinase signaling, which can be blocked by MEK 1/2 inhibitor (U 0126).
We found that most primary bile acids, secondary bile acids and glycine-conjugated bile acids at high concentration $(100 \mu \mathrm{M})$ significantly decreased the viability of CCA cells. This observation is in line with a previous report showing that $100-200 \mu \mathrm{M}$ of CA, DCA or CDCA inhibited growth of QBC939 cell, which is a human CCA cell line, by promoting cell apoptosis (23). Dai and colleagues reported that glycineconjugated bile acids including GCA, GDCA, and GCDCA at very high concentrations $(400-800 \mu \mathrm{M})$ stimulated growth of QBC939 cells (23). In addition, Werneburg and colleagues reported that $200 \mu \mathrm{M}$ of DCA induced growth of KMBC which is a human CCA cell line (24). However, we did not observe the growth promoting effects of these bile acids in our tested CCA cells; this may be due to the concentration range in our study $(0.1-100 \mu \mathrm{M})$ being far lower than the concentration range in the above mentioned studies or may be due to the difference in CCA cell lines used. Among eleven forms of bile acids, we only observed the growth promoting effect in TLCA-treated RMCCA-1 cells (Table I). Futhermore, the increased number of the S-phase cells which reflected active cell division together with the increase in level of cyclin D1, which is a key protein regulating G1/S transition in cell cycle confirmed the growth promoting effect of TLCA.

Accumulation of bile acids triggers inflammation and tumor progression $(25,26)$. In animal models, bile acid concentrations were increased 27 -fold in liver and 1,400-fold in serum, after bile duct ligation and remained up to 14 days (27). Bile acid levels are altered in many diseases. For example, 
a pregnant patient who had an intrahepatic cholestasis was found to have a predominant increase in cholic acid conjugated with taurine and glycine (28). Moreover, it has been reported that the levels of glycine conjugated bile acids are increased in CCA patients (29). The exact concentration of TLCA in human liver has not been reported, but the highest level of TLCA can be found in the gallbladder and near the ampulla of Vater. Moreover, the concentration of TLCA in the gallbladder is $0.4 \mathrm{mM}$, and most TLCA is excreted in feces: a small amount of TLCA is absorbed back to enterohepatic circulation (3). There is a study that reported TLCA concentration of $2.07 \mathrm{pmol} / \mathrm{mg}$ dry weight of rat liver tissue (30). In normal situations, the ratio of glycine and taurine conjugates is at $\sim 3: 1$, but in cholestasis taurine conjugation is increased (2). Moreover, TLCA has been reported to increase in the serum of cirrhotic patients (31). Therefore, it is possible that the concentration range of TLCA used in this study may be found in CCA patients.

It has been documented that M3 mAChR plays an important role in the differentiation and metastasis of CCA (18). By using a non-selective $\mathrm{mAChR}$ antagonist, atropine, we found that the activation of $\mathrm{mAChR}$ plays a crucial role in the growth promoting effect of TLCA in RMCCA- 1 cells. In line with a previous colon cancer $\mathrm{H} 508$ cell study which overexpressed M3 mAChR, TLCA was found to interact with M3 mAChR, thereby causing an increase in inositol triphosphate $3\left(\mathrm{IP}_{3}\right)$ and cell proliferation (8). Furthermore, it has been reported that TLCA can bind with M3 AChR but cannot bind to other types of mAChR in Chinese hamster ovary ( $\mathrm{CHO}$ ) cells (9). The differential sensitivity of the CCA cell lines to TLCA-induced cell growth could be explained in part due to the difference in molecular characteristics of the different CCA cell lines. The growth promoting effect of TLCA was not evidenced in HuCCA-1 cells. We found that the cholinergic components, including CHT, ChAT, AChE, M3 mAChR and $\alpha 7 \mathrm{nAChR}$, were present in both HuCCA-1 and RMCCA-1 cells. The cholinergic responses to $\mathrm{mAChR}$ agonists, including carbachol and Oxo-M were only evidenced in RMCCA-1 cells. It is reasonable to postulate that the presence of functional cholinergic system in CCA cells may explain the different growth promoting response of TLCA. On the other hand, a previous study in QBC939 cells showed that pilocarpine, a non-selective $\mathrm{mAChR}$ agonist, inhibits cell proliferation while atropine can reverse this inhibitory effect (18). This opposite result may depend on cell types, mutation patterns of $\mathrm{mAChR}$, and experimental design. It should be emphasized that signaling pathway involving receptors are in a dynamic state. Therefore, time course of exposure and the concentration used are important.

It is well documented that cholinergic system plays an important role in inflammation; the blockage of $\mathrm{mAChR}$ produced anti-inflammation properties in LPS-induced lung inflammation (32). Furthermore, selective mAChR antagonists have been used to treat many diseases such as skin inflammatory disorders, asthma, intestinal inflammation and systemic inflammation diseases (33). Moreover, our results showed that COX-2, a key inflammatory marker protein, in these two cell lines is different. RMCCA-1 showed a low level of COX-2 while HuCCA-1 showed a high level. Therefore, the inflammation background of CCA may influence the functional cholinergic system which involves the response of TLCA. However this hypothesis remains inconclusive and needs to be further investigated.

There are studies indicating that bile acids stimulate cell signaling and cell growth through the EGFR (4). It has been reported that DCA can induce caudal homeobox gene 2 (CDX2) through activation of EGFR in human mucosal epithelial SEG-1 cells (34). Moreover, there are reports of bile acids, including DCA, CDCA and TCDCA, induced cell growth and EGFR activation by the transforming growth factor- $\alpha$ (TGF- $\alpha)$, ligand-dependent mechanism in human CCA KMBC and normal cholangiocyte H69 cell lines (24). By using the specific EGFR inhibitor AG1478, we made it clear that EGFR/ERK1/2 signaling pathway is involved in the growth promoting effect of TLCA in RMCCA-1 cells. This finding is related to a previous report by Cheng and Raufman showing that conjugated secondary bile acids, including TLCA, TDCA and GDCA stimulate colon cancer H508 cell proliferation by activation of EGFR and post-EGFR/ERK1/2 signaling pathway (4).

It has been reported that TLCA induced growth of colon cancer cells through the M3 mAChR-transactived EGFR signaling pathway (10). Our study showed that atropine could not prevent the phosphorylation of EGFR and ERK1/2induced by TLCA at $1 \mathrm{~h}$ of exposure (Fig. 7), suggesting that M3 mAChR may not transactivate EGFR in RMCCA-1 cells. However, both atropine and AG1478 completely inhibited the growth stimulating effect of TLCA (Figs. 6 and 8). Therefore, the transactivation of EGFR by $\mathrm{mAChR}$ cannot be ruled out. More selective M3 mAChR antagonist or time course studies on the effect of atropine (a non-selective mAChR antagonist) on the activation of EGFR and ERK1/2 are required.

The present study provides evidence of the TLCA mechanism that activates CCA cell proliferation and which may provide a basis for therapeutic strategies to treat CCA patients. The results of the study suggest that TLCA induces the proliferation of CCA via $\mathrm{mAChR}$ and EGFR/ERK1/2 signaling pathway (Fig. 10). Moreover, the presence of functional cholinergic system and inflammation background of CCA plays a crucial role in the growth promoting effect of TLCA.

\section{Acknowledgements}

This study was supported by the Center of Excellence on Environmental Health and Toxicology, Chulabhorn Graduate Institute and Chulabhorn Research Institute. We would like to express our great appreciation to Ms. Kanjana Chaiyot for her technical assistance on cell culture.

\section{References}

1. Patel T: Cholangiocarcinoma - controversies and challenges. Nat Rev Gastroenterol Hepatol 8: 189-200, 2011.

2. Raufman JP, Cheng K and Zimniak P: Activation of muscarinic receptor signaling by bile acids: Physiological and medical implications. Dig Dis Sci 48: 1431-1444, 2003.

3. Bernstein H, Bernstein C, Payne CM, Dvorakova K and Garewal H: Bile acids as carcinogens in human gastrointestinal cancers. Mutat Res 589: 47-65, 2005.

4. Cheng K and Raufman JP: Bile acid-induced proliferation of a human colon cancer cell line is mediated by transactivation of epidermal growth factor receptors. Biochem Pharmacol 70: 1035-1047, 2005 
5. Fujino T, Takeuchi A, Maruko-Ohtake A, Ohtake Y, Satoh J, Kobayashi T, Tanaka T, Ito H, Sakamaki R, Kashimura R, et al: Critical role of farnesoid $\mathrm{X}$ receptor for hepatocellular carcinoma cell proliferation. J Biochem 152: 577-586, 2012.

6. Liu R, Zhao R, Zhou X, Liang X, Campbell DJ, Zhang X, Zhang L, Shi R, Wang G, Pandak WM, et al: Conjugated bile acids promote cholangiocarcinoma cell invasive growth via activation of sphingosine 1-phosphate receptor 2. Hepatology 60: 908-918, 2014.

7. Casaburi I, Avena P, Lanzino M, Sisci D, Giordano F, Maris P, Catalano S, Morelli C and Andò S: Chenodeoxycholic acid through a TGR5-dependent CREB signaling activation enhances cyclin D1 expression and promotes human endometrial cancer cell proliferation. Cell Cycle 11: 2699-2710, 2012.

8. Cheng K, Chen Y, Zimniak P, Raufman JP, Xiao Y and Frucht H: Functional interaction of lithocholic acid conjugates with M3 muscarinic receptors on a human colon cancer cell line. Biochim Biophys Acta 1588: 48-55, 2002.

9. Raufman JP, Chen Y, Cheng K, Compadre C, Compadre L and Zimniak P: Selective interaction of bile acids with muscarinic receptors: A case of molecular mimicry. Eur J Pharmacol 457: 77-84, 2002

10. Shah N, Khurana S, Cheng K and Raufman JP: Muscarinic receptors and ligands in cancer. Am J Physiol Cell Physiol 296 C221-C232, 2009

11. Trombino S, Bisio A, Catassi A, Cesario A, Falugi C and Russo P: Role of the non-neuronal human cholinergic system in lung cancer and mesothelioma: Possibility of new therapeutic strategies. Curr Med Chem Anticancer Agents 4: 535-542, 2004.

12. Español AJ, de la Torre E, Fiszman GL and Sales ME: Role of non-neuronal cholinergic system in breast cancer progression. Life Sci 80: 2281-2285, 2007.

13. Belo A, Cheng K, Chahdi A, Shant J, Xie G, Khurana S and Raufman JP: Muscarinic receptor agonists stimulate human colon cancer cell migration and invasion. Am J Physiol Gastrointest Liver Physiol 300: G749-G760, 2011.

14. Parnell EA, Calleja-Macias IE, Kalantari M, Grando SA and Bernard HU: Muscarinic cholinergic signaling in cervical cancer cells affects cell motility via ERK1/2 signaling. Life Sci 91: 1093-1098, 2012

15. Rayford W, Noble MJ, Austenfeld MA, Weigel J, Mebust WK and Shah GV: Muscarinic cholinergic receptors promote growth of human prostate cancer cells. Prostate 30: 160-166, 1997.

16. Paleari L, Grozio A, Cesario A and Russo P: The cholinergic system and cancer. Semin Cancer Biol 18: 211-217, 2008.

17. Schuller HM: Is cancer triggered by altered signalling of nicotinic acetylcholine receptors? Nat Rev Cancer 9: 195-205, 2009.

18. Feng YJ, Zhang BY, Yao RY and Lu Y: Muscarinic acetylcholine receptor M3 in proliferation and perineural invasion of cholangiocarcinoma cells. Hepatobiliary Pancreat Dis Int 11: 418-423, 2012.

19. Fava G, Marzioni M, Francis H, Glaser S, Demorrrow S, Ueno Y, Benedetti A and Alpini G: Novel interaction of bile acid and neural signaling in the regulation of cholangiocyte function. Hepatol Res 37 (Suppl 3): S420-S429, 2007.

20. Sirisinha S, Tengchaisri T, Boonpucknavig S, Prempracha N, Ratanarapee S and Pausawasdi A: Establishment and characterization of a cholangiocarcinoma cell line from a Thai patient with intrahepatic bile duct cancer. Asian Pac J Allergy Immunol 9: $153-157,1991$.
21. Rattanasinganchan $\mathrm{P}$, Leelawat $\mathrm{K}$, Treepongkaruna SA, Tocharoentanaphol C, Subwongcharoen S, Suthiphongchai T and Tohtong R: Establishment and characterization of a cholangiocarcinoma cell line (RMCCA-1) from a Thai patient. World J Gastroenterol 12: 6500-6506, 2006.

22. LeSage G, Alvaro D, Benedetti A, Glaser S, Marucci L, Baiocchi L, Eisel W, Caligiuri A, Phinizy JL, Rodgers R, et al: Cholinergic system modulates growth, apoptosis, and secretion of cholangiocytes from bile duct-ligated rats. Gastroenterology 117: 191-199, 1999.

23. Dai J, Wang H, Dong Y, Zhang Y and Wang J: Bile acids affect the growth of human cholangiocarcinoma via NF- $\kappa \mathrm{B}$ pathway. Cancer Invest 31: 111-120, 2013.

24. Werneburg NW, Yoon JH, Higuchi H and Gores GJ: Bile acids activate EGF receptor via a TGF-alpha-dependent mechanism in human cholangiocyte cell lines. Am J Physiol Gastrointest Liver Physiol 285: G31-G36, 2003.

25. Degirolamo C, Modica S, Palasciano G and Moschetta A: Bile acids and colon cancer: Solving the puzzle with nuclear receptors. Trends Mol Med 17: 564-572, 2011.

26. Renga B, Mencarelli A, Cipriani S, D'Amore C, Carino A, Bruno A, Francisci D, Zampella A, Distrutti E and Fiorucci S: The bile acid sensor FXR is required for immune-regulatory activities of TLR-9 in intestinal inflammation. PLoS One 8: e54472, 2013.

27. Zhang Y, Hong JY, Rockwell CE, Copple BL, Jaeschke H and Klaassen CD: Effect of bile duct ligation on bile acid composition in mouse serum and liver. Liver Int 32: 58-69, 2012

28. Tribe RM, Dann AT, Kenyon AP, Seed P, Shennan AH and Mallet A: Longitudinal profiles of 15 serum bile acids in patients with intrahepatic cholestasis of pregnancy. Am J Gastroenterol 105: 585-595, 2010.

29. Sharif AW, Williams HR, Lampejo T, Khan SA, Bansi DS, Westaby D, Thillainayagam AV, Thomas HC, Cox IJ and TaylorRobinson SD: Metabolic profiling of bile in cholangiocarcinoma using in vitro magnetic resonance spectroscopy. HPB (Oxford) 12: 396-402, 2010

30. Bobeldijk I, Hekman M, de Vries-van der Weij J, Coulier L, Ramaker R, Kleemann R, Kooistra T, Rubingh C, Freidig A and Verheij E: Quantitative profiling of bile acids in biofluids and tissues based on accurate mass high resolution LC-FT-MS: Compound class targeting in a metabolomics workflow. J Chromatogr B Analyt Technol Biomed Life Sci 871: 306-313, 2008.

31. Greco AV and Mingrone G: Serum bile acid concentrations in mild liver cirrhosis. Clin Chim Acta 221: 183-189, 1993.

32. Xu ZP, Yang K, Xu GN, Zhu L, Hou LN, Zhang WH, Chen HZ and Cui YY: Role of M3 mAChR in in vivo and in vitro models of LPS-induced inflammatory response. Int Immunopharmacol 14: 320-327, 2012.

33. Sales ME: Muscarinic receptors as targets for anti-inflammatory therapy. Curr Opin Investig Drugs 11: 1239-1245, 2010.

34. Avissar NE, Toia L, Hu Y, Watson TJ, Jones C, Raymond DP, Matousek A and Peters JH: Bile acid alone, or in combination with acid, induces CDX2 expression through activation of the epidermal growth factor receptor (EGFR). J Gastrointest Surg 13: 212-222, 2009. 